\title{
Assessment of the microbial quality of river water sources in rural Venda communities in South Africa
}

\author{
CL Obi ${ }^{\star}$, N Potgieter, PO Bessong and G Matsaung \\ Department of Microbiology, University of Venda for Science and Technology, P/Bag x5050, Thohoyandou 0950, South Africa
}

\begin{abstract}
The microbial quality of several, untreated surface water sources, used by rural communities in the Venda region of South Africa, was assessed to determine its safety for human consumption and to highlight the possible occurrence of water-borne diseases. The water sources studied were six sampling points on the Levubu River, Vuwani, Mutale, Ngwedi, Tshinane, Makonde, Mutshindudi and Mudaswali Rivers. Heterotrophic plate counts, faecal and total coliforms, enterococci and somatic coliphage counts were performed according to standard methods to determine the microbiological quality of the water sources. The presence of enteric pathogens such as Salmonella, Shigella, Campylobacter, Plesiomonas, Aeromonas and Vibrio was also determined.

Results obtained showed that the minimum and maximum counts with regard to all the sampling points investigated were $1.5 \times 10^{3} \mathrm{cfu} \cdot \mathrm{ml}^{-1}$ and $6.3 \times 10^{4} \mathrm{cfu} \cdot \mathrm{ml}^{-1}$ for faecal coliforms, $6.0 \times 10^{2} \mathrm{cfu} \cdot \mathrm{ml}^{-1}$ and $3.7 \times 10^{4} \mathrm{cfu} \cdot \mathrm{ml}^{-1}$ for total coliforms, $1.8 \times 10^{2}$ $\mathrm{cfu} \cdot \mathrm{ml}^{-1}$ and $1.3 \times 10^{6} \mathrm{cfu} \cdot \mathrm{ml}^{-1}$ for heterotrophic plate counts, $1.0 \times 10^{1} \mathrm{cfu} \cdot \mathrm{ml}^{-1}$ and $2.5 . \times 10^{4} \mathrm{cfu} \cdot \mathrm{ml}^{-1}$ for enterococci and 0 and 13 pfu $\cdot 100 \mathrm{ml}^{-1}$ for somatic coliphages. The results for the indicators were higher than the acceptable maximum limits prescribed by the Department of Water and Forestry of South Africa. According to these guidelines, the maximum values are as follows: $0 \mathrm{cfu} \cdot 100 \mathrm{ml}^{-1}$ for faecal coliforms, $5 \mathrm{cfu} \cdot 100 \mathrm{ml}^{-1}$ for total coliforms, $1.0 \times 10^{2} \mathrm{cfu} \cdot \mathrm{ml}^{-1}$ for heterotrophic plate count, $0 \mathrm{cfu} \cdot \mathrm{ml}^{-1}$ for enterococci and $1 \mathrm{pfu} \cdot 100 \mathrm{ml}^{-1}$ for somatic coliphages. Salmonella, Shigella, Vibro, Campylobacter, Aeromonas and Plesiomonas species were isolated from several of the water sources investigated.

These untreated water sources are used for drinking and domestic purposes and pose a serious threat to the health of the consumers and therefore calls for urgent intervention by government.
\end{abstract}

\section{Introduction}

In developing countries such as South Africa, most of the rural communities are poverty-stricken, lack access to potable water supplies and rely mainly on river, stream, well and pond water sources for their daily water needs (Nevondo and Cloete, 1991). Water from these sources is used directly by the inhabitants and the water sources are faecally contaminated and devoid of treatment (WHO, 1993). Consequently, a significant proportion of residents in rural communities in South Africa are exposed to water-borne disease and their complications (Schalekamp, 1990). These diseases include campylobacteriosis, shigellosis, salmonellosis, cholera, yersiniosis and a variety of other bacterial, as well as fungal, viral and parasitic infections (Grabow, 1996; Genthe and Seager, 1996). These diseases cause crippling, devastating and debilitating effects on rural residents and further exacerbate the already strained health burden and facilities in the country. It is therefore not an option but an imperative to critically monitor the microbial quality of water supply in rural areas in order to highlight the poor quality of water supplies and to provide the impetus for sustained government intervention. Indeed, the centrality of water supply to rural communities is one of the great challenges of sustainable development because it impinges on achieving the objectives of improving health, income, living conditions and ensuring equitable and sustainable use of natural resources and a better life for all in South Africa and other developing countries (Acho-Chi, 2001).

Although government has made some efforts to ensure access to potable water supply by rural residents in South Africa, these

* To whom all correspondence should be addressed.

푱 015-962-8186; fax: 015-962-8186; e-mail: Larryobi@lantic.net, or Obil@univen.ac.za

Received 8 February 2002; accepted in revised form 24 April 2002. projects have been fraught with financial and human resource constraints, making it unlikely that high-quality water will be made available to the bulk of rural residents in the future (Nevondo and Cloete, 1999). In areas where potable water supplies have been provided, these supplies are unreliable and insufficient, forcing residents to revert to traditional contaminated river sources (WRC, 1993; Nevondo and Cloete, 1999). The major health risk associated with these drinking water sources is contamination by human or animal faeces (Lehloesa and Muyima, 2000). Since it is impractical to test water supply for all pathogens related to water-borne diseases due to the complexity of the testing, time and cost (Lehloesa and Muyima, 2000), indicator organisms are used (Hazen, 1988; Grabow, 2001). However, no simple indicator that complies with all the criteria is available, hence more than one indicator organism is employed (Genthe and Seager, 1996).

In spite of the problem of poor water quality in rural areas, few data exist on the bacterial quality of water supply in these settings, since most studies approach the problem by focusing on urban communities (Nevondo an Cloete, 1999). In this study indicators of pollution (faecal coliforms, total coliforms, heterotrophic plate counts, enterococci and somatic phages) were used to determine the microbial quality of water sources of rural communities in the Venda region and to compare these results with guideline values (DWAF, 1996).

\section{Materials and methods}

\section{Study areas}

The study sites were rural communities in the Venda region of the Northern Province, South Africa. The main water sources in the rural communities were identified and sampled. They comprised 


\begin{tabular}{|c|c|c|c|c|}
\hline \multicolumn{5}{|c|}{$\begin{array}{c}\text { TABLE } 1 \\
\text { Bacteriological assessment of water quality from drinking water river sources in rural } \\
\text { Venda communities }\end{array}$} \\
\hline & \multirow{3}{*}{$\begin{array}{l}\text { Faecal coliform } \\
-\mathrm{cfu} \cdot \mathrm{ml}^{-1} \\
\text { Limit for no risk } \\
0 \mathrm{cfu} \cdot 100 \mathrm{ml}^{-1}\end{array}$} & \multirow{3}{*}{$\begin{array}{l}\text { Total coliform } \\
-\mathrm{cfu} \cdot \mathrm{ml}^{-1} \\
\text { Limit for no risk } \\
0 \mathrm{cfu} \cdot 100 \mathrm{ml}^{-1}\end{array}$} & \multirow{3}{*}{$\begin{array}{l}\text { Heterotrophic } \\
-\mathrm{cfu} \cdot \mathrm{ml}^{-1} \\
\text { Limit for no risk } \\
0 \mathrm{cfu} \cdot 100 \mathrm{ml}^{-1}\end{array}$} & \multirow{3}{*}{$\begin{array}{l}\text { Enterococci } \\
\text { Limit for no risk } \\
0 \mathrm{cfu} \cdot 100 \mathrm{ml}^{-1}\end{array}$} \\
\hline vatet sunes & & & & \\
\hline Levubu River & & & & \\
\hline Masetoni point & $\begin{array}{l}\text { Min: } 1.5 \times 10^{3} \\
\text { Max: } 6.3 \times 10^{4} \\
\text { Mean: } 3.3 \times 10^{4} \\
\text { SD: } 2.4 \times 10^{3}\end{array}$ & $\begin{array}{l}\text { Min: } 6.0 \times 10^{2} \\
\text { Max: } 7.6 \times 10^{3} \\
\text { Mean: } 3.2 \times 10^{3} \\
\text { SD: } 8.0 \times 10^{2}\end{array}$ & $\begin{array}{l}\text { Min: } 6.0 \times 10^{3} \\
\text { Max: } 1.3 \times 10^{6} \\
\text { Mean: } 6.5 \times 10^{5} \\
\text { SD: } 3.5 \times 10^{5}\end{array}$ & $\begin{array}{l}\text { Min: } 2.0 \times 10^{3} \\
\text { Max: } 5.5 \times 10^{3} \\
\text { Mean: } 3,75 \times 10^{3} \\
\text { SD: } 1.5 \times 10^{2}\end{array}$ \\
\hline Mhinga point & $\begin{array}{l}\text { Min: } 5.2 \times 10^{3} \\
\text { Max: } 1.72 \times 10^{4} \\
\text { Mean: } 1.12 \times 10^{4} \\
\text { SD: } 6.5 \times 10^{4}\end{array}$ & $\begin{array}{l}\text { Min: } 8.9 \times 10^{2} \\
\text { Max: } 2.3 \times 10^{3} \\
\text { Mean: } 1.6 \times 10^{3} \\
\text { SD: } 7.2 \times 10^{2}\end{array}$ & $\begin{array}{l}\text { Min: } 5.0 \times 10^{3} \\
\text { Max: } 3.1 \times 10^{4} \\
\text { Mean: } 1.8 \times 10^{4} \\
\text { SD: } 1.3 \times 10^{4}\end{array}$ & $\begin{array}{l}\text { Min: } 5.0 \times 10^{2} \\
\text { Max: } 2.3 \times 10^{3} \\
\text { Mean: } 1.4 \times 10^{3} \\
\text { SD: } 9.0 \times 10^{2}\end{array}$ \\
\hline Didi point & $\begin{array}{l}\text { Min: } 4.1 \times 10^{2} \\
\text { Max: } 7.5 \times 10^{2} \\
\text { Mean: } 5.8 \times 10^{2} \\
\text { SD: } 1.8 \times 10^{2}\end{array}$ & $\begin{array}{l}\text { Min: } 4.9 \times 10^{3} \\
\text { Max: } 1.5 \times 10^{4} \\
\text { Mean: } 9.95 \times 10^{3} \\
\text { SD: } 5.0 \times 10^{2}\end{array}$ & $\begin{array}{l}\text { Min: } 7.7 \times 10^{3} \\
\text { Max: } 2.6 \times 10^{4} \\
\text { Mean: } 1.7 \times 10^{4} \\
\text { SD: } 1.0 \times 10^{4}\end{array}$ & $\begin{array}{l}\text { Min: } 1.0 \times 10^{3} \\
\text { Max: } 1.0 \times 10^{4} \\
\text { Mean: } 5.5 \times 10^{3} \\
\text { SD: } 5.5 \times 10^{2}\end{array}$ \\
\hline Tshikonela point & $\begin{array}{l}\text { Min: } 9.0 \times 10^{2} \\
\text { Max: } 1.5 \times 10^{3} \\
\text { Mean: } 1.2 \times 10^{3} \\
\text { SD: } 3.3 \times 10^{2}\end{array}$ & $\begin{array}{l}\text { Min: } 1.1 \times 10^{3} \\
\text { Max: } 1.8 \times 10^{3} \\
\text { Mean: } 1.5 \times 10^{3} \\
\text { SD: } 4.3 \times 10^{2}\end{array}$ & $\begin{array}{l}\text { Min: } 9.6 \times 10^{2} \\
\text { Max: } 1.4 \times 10^{4} \\
\text { Mean: } 7.5 \times 10^{3} \\
\text { SD: } 2.3 \times 10^{3}\end{array}$ & $\begin{array}{l}\text { Min: } 1.2 \times 10^{3} \\
\text { Max: } 3.1 \times 10^{3} \\
\text { Mean: } 2.2 \times 10^{3} \\
\text { SD: } 1.0 \times 10^{2}\end{array}$ \\
\hline Grootpad point & $\begin{array}{l}\text { Min: } 6.1 \times 10^{3} \\
\text { Max: } 1.2 \times 10^{4} \\
\text { Mean: } 9.0 \times 10^{3} \\
\text { SD: } 2.9 \times 10^{3}\end{array}$ & $\begin{array}{l}\text { Min: } 1.3 \times 10^{4} \\
\text { Max: } 2.1 \times 10^{4} \\
\text { Mean: } 1.7 \times 10^{4} \\
\text { SD: } 4.3 \times 10^{2}\end{array}$ & $\begin{array}{l}\text { Min: } 1.8 \times 10^{2} \\
\text { Max: } 2.0 \times 10^{3} \\
\text { Mean: } 1.1 \times 10^{3} \\
\text { SD: } 2.8 \times 10^{2}\end{array}$ & $\begin{array}{l}\text { Min: } 4.0 \times 10^{3} \\
\text { Max: } 2.1 \times 10^{4} \\
\text { Mean: } 1.3 \times 10^{4} \\
\text { SD: } 8.6 \times 10^{3}\end{array}$ \\
\hline Mutoti point & $\begin{array}{l}\text { Min: } 5.6 \times 10^{3} \\
\text { Max: } 7.2 \times 10^{2} \\
\text { Mean: } 2.5 \times 10^{3} \\
\text { SD: } 1.0 \times 10^{3}\end{array}$ & $\begin{array}{l}\text { Min: } 9.2 \times 10^{2} \\
\text { Max: } 1.45 \times 10^{3} \\
\text { Mean: } 5.0 \times 10^{3} \\
\text { SD: } 1.91 \times 10^{4}\end{array}$ & $\begin{array}{l}\text { Min: } 1.0 \times 10^{3} \\
\text { Max: } 1.38 \times 10^{2} \\
\text { Mean: } 1.5 \times 10^{3} \\
\text { SD: } 3.0 \times 10^{3}\end{array}$ & $\begin{array}{l}\text { Min: } 1.9 \times 10^{3} \\
\text { Max: } 2.1 \times 10^{4} \\
\text { Mean: } 3.4 \times 10^{3} \\
\text { SD: } 2.5 \times 10^{4}\end{array}$ \\
\hline Vuwani point & $\begin{array}{l}\text { Min: } 2.9 \times 10^{2} \\
\text { Max: } 1.1 \times 10^{4} \\
\text { Mean: } 5.6 \times 10^{3} \\
\text { SD: } 4.2 \times 10^{3}\end{array}$ & $\begin{array}{l}\text { Min: } 7.3 \times 10^{3} \\
\text { Max: } 1.8 \times 10^{4} \\
\text { Mean: } 1.3 \times 10^{4} \\
\text { SD: } 6.4 \times 10^{3}\end{array}$ & $\begin{array}{l}\text { Min: } 7.0 \times 10^{3} \\
\text { Max: } 2.7 \times 10^{5} \\
\text { Mean: } 1.4 \times 10^{5} \\
\text { SD: } 1.1 \times 10^{4}\end{array}$ & $\begin{array}{l}\text { Min: } 1.0 \times 10^{1} \\
\text { Max: } 5.1 \times 10^{2} \\
\text { Mean: } 2.6 \times 10^{1} \\
\text { SD: } 2.5 \times 10^{1}\end{array}$ \\
\hline Mutale point & $\begin{array}{l}\text { Min: } 5.6 \times 10^{2} \\
\text { Max: } 2.0 \times 10^{3} \\
\text { Mean: } 1.3 \times 10^{4} \\
\text { SD: } 2.5 \times 10^{2}\end{array}$ & $\begin{array}{l}\text { Min: } 9 . .2 \times 10^{3} \\
\text { Max: } 1.9 \times 10^{4} \\
\text { Mean: } 1.4 \times 10^{4} \\
\text { SD: } 5.0 \times 10^{3}\end{array}$ & $\begin{array}{l}\text { Min: } 1.0 \times 10^{3} \\
\text { Max: } 3.0 \times 10^{4} \\
\text { Mean: } 1.6 \times 10^{4} \\
\text { SD: } 1.4 \times 10^{3}\end{array}$ & $\begin{array}{l}\text { Min: } 1.9 \times 10^{2} \\
\text { Max: } 2.5 \times 10^{3} \\
\text { Mean: } 1.3 \times 10^{3} \\
\text { SD: } 3.45 \times 10^{2}\end{array}$ \\
\hline Ngwedi River & $\begin{array}{l}\text { Min: } 1.8 \times 10^{1} \\
\text { Max: } 8.2 \times 10^{2} \\
\text { Mean: } 4.2 \times 10^{3} \\
\text { SD: } 4.0 \times 10^{2}\end{array}$ & $\begin{array}{l}\text { Min: } 2.8 \times 10^{3} \\
\text { Max: } 3.7 \times 10^{4} \\
\text { Mean: } 2.0 \times 10^{4} \\
\text { SD: } 2.1 \times 10^{3}\end{array}$ & $\begin{array}{l}\text { Min: } 6.2 \times 10^{3} \\
\text { Max: } 7.9 \times 10^{4} \\
\text { Mean: } 7.1 \times 10^{4} \\
\text { SD: } 5.4 \times 10^{4}\end{array}$ & $\begin{array}{l}\text { Min: } 6.6 \times 10^{3} \\
\text { Max: } 2.2 \times 10^{4} \\
\text { Mean: } 1.4 \times 10^{4} \\
\text { SD: } 1.9 \times 10^{3}\end{array}$ \\
\hline Tshinane River & $\begin{array}{l}\text { Min: } 7.4 \times 10^{2} \\
\text { Max: } 3.9 \times 10^{3} \\
\text { Mean: } 2.3 \times 10^{3} \\
\text { SD: } 5.0 \times 10^{2}\end{array}$ & $\begin{array}{l}\text { Min: } 2.0 \times 10^{4} \\
\text { Max: } 3.4 \times 10^{4} \\
\text { Mean: } 2.7 \times 10^{4} \\
\text { SD: } 2.6 \times 10^{3}\end{array}$ & $\begin{array}{l}\text { Min: } 1.9 \times 10^{2} \\
\text { Max: } 1.7 \times 10^{3} \\
\text { Mean: } 9.5 \times 10^{2} \\
\text { SD: } 4.4 \times 10^{2}\end{array}$ & $\begin{array}{l}\text { Min: } 4.0 \times 10^{1} \\
\text { Max: } 3.2 \times 10^{2} \\
\text { Mean: } 1.8 \times 10^{2} \\
\text { SD: } 1.5 \times 10^{2}\end{array}$ \\
\hline
\end{tabular}

Vuwani, Mutshindudi, Tshinane, Ngwedi, Mutale, Mudaswali Rivers and various points in the Levubu River. The catchment points on the Levubu River comprised Masetoni, Mhinga, Mutoti, Dididi, Tshikonelo, Vuwani and Grootpad. Makonde and Mudaswali Fountains were also included in the study.

\section{Sample collection}

The collection of water samples from the river water sources mentioned above was done weekly over a period of five months (April to October, 2001). Water samples were collected aseptically into 1 I Nalgene containers and transported on ice to the base laboratories at the Department of Microbiology, University of 
Venda for Science and Technology and the Department of Medical Virology, University of Pretoria, South Africa. Microbiological investigations were done within 4 to $6 \mathrm{~h}$ after collection.

\section{Microbiological analyses}

Microbiological analyses of water samples were performed as described (Standard Methods, 1998; Nevondo and Cloete, 1999). Briefly, for heterotrophic bacteria, the spread-plate method was done on nutrient agar (Biolab) and plates were incubated at $37^{\circ} \mathrm{C}$ for $48 \mathrm{~h}$. Total coliforms were assessed on mEndo-agar (Merck) after $24 \mathrm{~h}$ with an incubation temperature of $37^{\circ} \mathrm{C}$. Faecal coliforms were enumerated on $\mathrm{M}-\mathrm{Fc}$ medium and incubated at $44.5^{\circ} \mathrm{C}$ for $24 \mathrm{~h}$. The $\mathrm{mEnterococcus}(\mathrm{mE})$ agar for enterococci was used and incubation was at $37^{\circ} \mathrm{C}$ for $48 \mathrm{~h}$. Selected colonies were picked from a membrane and streaked for isolation onto the surface of a brain heart infusion agar plate and incubated at $35^{\circ} \mathrm{C}$ for $24 \mathrm{~h}$ to $48 \mathrm{~h}$. Enterococci were identified by their growth at $45^{\circ} \mathrm{C}$ in $6.5 \%$ Nad broth.

For somatic coliphage counts, the double agar layer plaque assay on phage agar described by Grabow et al. (1984) at $37^{\circ} \mathrm{C}$ for $18 \mathrm{~h}$ was used. Escherichia coli strain WG5, which is resistant to nalidixic acid, was used as host.

Bacterial pathogens were detected and enumerated using the membrane filtration method. Standard Methods (1998) were employed for the isolation and identification of Campylobacter, Aeromonas, Plesiomonas, Salmonella, Shigella, Vibro and Yersinia species. In brief, for the isolation of Campylobacter jejuni from stools, Skirrow's and Butzler's media were employed as previously described (Alabi and Odugbemi, 1990; Coker and Dosunmu-Ogunbi, 1984; Obi et al., 1997). Briefly, the plates were incubated at $42^{\circ} \mathrm{C}$ under microaerophilic conditions for $72 \mathrm{~h}$. Organisms were considered to be Campylobacter if they were S-shaped, Gram negative bacteria, motile, oxidase-positive, grew at $42^{\circ} \mathrm{C}$ but not at $25^{\circ} \mathrm{C}$ and sensitive to nalidixic acid. For the isolation of Aeromonas and Plesiomonas spp., specimens were inoculated onto Xylose deoxycholate citrate Agar (XDCA), incubated at $37^{\circ} \mathrm{C}$ for $24 \mathrm{~h}$. Non-xylose fermenting colonies on XDCA were screened for oxidase production (Alabi and Odugbemi, 1990). Oxidase-positive colonies were further confirmed as belonging to Aeromonas or Plesiomonas shigelloides using an established protocol (Von Graevenitz, 1985). For the isolation of other enteropathogens, the methods fully described by Ogunsanya et al. (1994) and Alabi and Odugbemi (1990) were employed. In brief, inoculations of faecal specimens were made on appropriate media such as McConkey agar (McA), Deoxycholate citrate agar (DCA) and thiocitrate bile salt (TCBS) agar. Specimens were also inoculated into enrichment broths, such as selenite $\mathrm{F}$ broth to enhance the isolation of Salmonella and Shigella spp., whereas alkaline peptone water (APW), $\mathrm{pH} 8.6$ was employed for the enrichment of Vibrio Cholerae, Plesiomonas and Aeromonas species. (Ogunsanya et al., 1994) The APW was subcultured onto TCBS agar, whereas XDCA and selenite F broth cultures were subcultured onto DCA and Salmonella-Shigella (SS) agar as previously reported (Ogunsanya et al., 1994). For the enrichment of Yersinia enterocolitica, nutrient broth supplemented with lysed sheep blood and Yersinia selective supplement (SR109, Oxoid)
TABLE 2 region of South Africa

Enteric organisms isolated

Escherichia coli, Plesiomonas shigelloides, Vibrio spp., Enterobacter cloacae, Shigella spp., Salmonella spp. Escherichia coli, Enterobacter cloacae, Vibrio spp. Escherichia coli, Salmonella spp., Shigella spp., Enterobacter cloacae.

Aeromonas hydrophila, Aeromonas caviae, Salmonella spp., Shigella spp., Vibrio spp.

Aeromonas hydrohila, Aeromonas caviae, Vibrio, Escherichia coli, Shigella spp.

Salmonella spp., Shigella spp., Aeromonas hydrophila, Vibrio spp.

Enterobacter cloacae, Vibrio spp., Escherichia coli Vibrio spp., Enterobacter cloacae, Shigella spp., Salmonella spp

Escherichia coli, Shigella spp., Aeromonas caviae, Vibrio spp.

Escherichia coli, Shigella spp., Vibrio spp., Aeromonas spp., Salmonella spp., Campylobacter spp.

Escherichia coli, Aeromonas spp., Campylobacterspp., Salmonella spp.

Escherichia coli, Plesiomonas shigelloides, Shigella spp., Campylobacter spp.

Shigella spp., Samonella spp., Aeromonas spp.

Escherichia coli, Shigella spp., Aeromonas hydrophila, Aeromonas caviae, Plesiomonas shigelloides, Vibrio spp.

were used. The inoculated broth media were subcultured onto Yersinia agar medium (Oxoid) after incubation at room temperature for $24 \mathrm{~h}$ (Simango et al., 1992). All inoculated media (enrichment and subculture) where incubated at $37^{\circ} \mathrm{C}$ for $24 \mathrm{~h}$. Biochemical tests as previously described (Joseph, 1987), were employed for definitive identification. Slide agglutination with specific antisera (Wellcome Reagents Ltd, Wellcome Research Laboratories, Beckenham) were used for serological diagnosis (Alabi and Odugbemi, 1990).

\section{Statistical analysis}

Student t-test was employed for statistical analyses.

\section{Results and discussion}

According to water quality guidelines for drinking water, the results indicated that the various water sources were of poor microbiological quality. The faecal coliform counts for the various sites were as follows, between $1.5 \times 10^{3}$ and $6.3 \times 10^{4} \mathrm{cfu} \cdot \mathrm{ml}^{-1}$ for Masetoni point, between $5.2 \times 10^{3}$ and $1.72 \times 10^{4} \mathrm{cfu} \cdot \mathrm{ml}^{-1}$ for Mhinga point, between $9.0 \times 10^{2}$ and $1.5 \times 10^{3} \mathrm{cfu} \cdot \mathrm{ml}^{-1}$ for Tshikonelo point, between $6.1 \times 10^{3}$ and $1.2 \times 10^{4} \mathrm{cfu} \cdot \mathrm{ml}^{-1}$ for Grootpad point, between 5.6. x $10^{3}$ and $1.0 \times 10^{4} \mathrm{cfu} \cdot \mathrm{ml}^{-1}$ for Mutoti point, between $4.1 \times 10^{2}$ and $7.5 \times 10^{2} \mathrm{cfu} \cdot \mathrm{ml}^{-1}$ for Dididi point, all of the Levubu River; between $5.6 \times 10^{3}$ and $2.0 \times 10^{4} \mathrm{cfu} \cdot \mathrm{ml}^{-1}$ for Mutale River, between $7.4 \times 10^{2}$ and $3.9 \times 10^{3} \mathrm{cfu} \cdot \mathrm{ml}^{-1}$ for Tshinane 


\begin{tabular}{|c|c|c|c|c|}
\hline \multicolumn{5}{|c|}{$\begin{array}{c}\text { TABLE } 3 \\
\text { Quality of drinking water from river sources in terms of somatic coliphage } \\
\text { counts using E. coli WG5 as host }\end{array}$} \\
\hline Water source & Minimum & Mean & $\begin{array}{l}\text { Standard } \\
\text { deviation }\end{array}$ & Maximum \\
\hline $\begin{array}{l}\text { Vuwani River } \\
\text { Ngwedi River } \\
\text { Mutale River } \\
\text { Makonde River } \\
\text { Tshinane River } \\
\text { Mudaswali River } \\
\text { Makonde Fountain } \\
\text { Mutshindudi River } \\
\text { Mudaswali Fountain } \\
\text { Levubu River (Grootpad point) } \\
\text { Levubu River (Dididi point) } \\
\text { Levubu River (Tshikonelo point) } \\
\text { Masetoni point } \\
\text { Mpingha point }\end{array}$ & $\begin{array}{c}0 \\
0 \\
0 \\
0 \\
0 \\
0 \\
0 \\
0 \\
0 \\
\mathrm{ND} \\
\mathrm{ND} \\
0 \\
\mathrm{ND} \\
\mathrm{ND}\end{array}$ & $\begin{array}{c}1.1 \\
2.88 \\
1.11 \\
0.22 \\
1.77 \\
0.77 \\
0 \\
0.88 \\
\\
\text { ND } \\
\text { ND } \\
1.77 \\
\text { ND } \\
\text { ND }\end{array}$ & $\begin{array}{c}1.96 \\
4.56 \\
1.26 \\
0.66 \\
2.6 \\
1.56 \\
0 \\
1.05 \\
0 \\
\mathrm{ND} \\
\mathrm{ND} \\
2.6 \\
\mathrm{ND} \\
\mathrm{ND}\end{array}$ & $\begin{array}{c}5 \\
13 \\
3 \\
2 \\
7 \\
3 \\
0 \\
3 \\
0 \\
\mathrm{ND} \\
\mathrm{ND} \\
7 \\
\mathrm{ND} \\
\mathrm{ND}\end{array}$ \\
\hline \multicolumn{5}{|c|}{ Limit for no risk $=0-1 \mathrm{pfu} \cdot 100 \mathrm{ml}^{-1}(\mathrm{DWAF}, 1996)$} \\
\hline
\end{tabular}

River and between $1.8 \times 10^{2}$ and $8.2 \times 10^{3} \mathrm{cfu} \cdot \mathrm{ml}^{-1}$ for Ngwedi river. However, according to DWAF (1998) the maximum limit for no risk of faecal coliforms is $0 \mathrm{cfu} \cdot 100 \mathrm{ml}^{-1}$.

Total coliform counts were in the following ranges: between $6.0 \times 10^{2}$ and $7.6 \times 10^{3} \mathrm{cfu} \cdot \mathrm{ml}^{-1}$ for Masetoni point, between $8.9 \times 10^{2}$ and $2.3 \times 10^{3} \mathrm{cfu} \cdot \mathrm{ml}^{-1}$ for Mhinga point, between $4.9 \times 10^{3}$ and 1.5 $\mathrm{x} 10^{4} \mathrm{cfu} \cdot \mathrm{ml}^{-1}$ for Didi point, $1.1 \times 10^{3}$ and $1.8 \times 10^{3} \mathrm{cfu} \cdot \mathrm{ml}^{-1}$ for Tshikonelo point, between $1.3 \times 10^{4}$ and $2.1 \times 10^{4} \mathrm{cfu} \cdot \mathrm{ml}^{-1}$ for Grootpad point, and $9.2 \times 10^{3}$ and $1.91 \times 10^{4} \mathrm{cfu} \cdot \mathrm{ml}^{-1}$ for Mutoti point of Levubu River; $9.2 \times 10^{3}$ and $1.9 \times 10^{4} \mathrm{cfu} \cdot \mathrm{ml}^{-1}$ for Mutale River and between $2.0 \times 10^{4}$ and $3.4 \times 10^{4} \mathrm{cfu} \cdot \mathrm{ml}^{-1}$ for Tshinane River, and $2.8 \times 10^{3}$ and $3.7 \times 10^{4} \mathrm{cfu} \cdot \mathrm{ml}^{-1}$ for Ngwedi River. The counts exceeded the $5 \mathrm{cfu} \cdot 100 \mathrm{ml}^{-1}$, which is the maximum recommended limit for no risk (DWAF, 1996: WRC, 1998).

Similarly, heterotrophic bacterial counts were in the range of $6.0 \times 10^{3}$ and $1.3 \times 10^{6} \mathrm{cfu} \cdot \mathrm{ml}^{-1}$ for Masetoni, between $5.0 \times 10^{3}$ and $3.1 \times 10^{4} \mathrm{cfu} \cdot \mathrm{ml}^{-1}$ for Mhinga, between $7.7 \times 10^{3}$ and $22.6 \times 10^{4}$ for Didi, between $9.6 \times 10^{2}$ and $1.4 \times 10^{4} \mathrm{cfu} \cdot \mathrm{ml}^{-1}$ for Tshikonelo, between $1.8 \times 10^{2}$ and $2.0 \times 10^{3} \mathrm{cfu} \cdot \mathrm{ml}^{-1}$ for Grootpad, $1.0 \times 10^{3}$ and $3.0 \times 10^{3} \mathrm{cfu} \cdot \mathrm{ml}^{-1}$ for Mutoti points of the Levubu River. The counts were between $1.0 \times 10^{3}$ and $3.0 \times 10^{4} \mathrm{cfu} \cdot \mathrm{ml}^{-1}$ for Mutale River and between $1.9 \times 10^{2}$ and $1.7 \times 10^{3} \mathrm{cfu} \cdot \mathrm{ml}^{-1}$ for Tshinane River, between $7.0 \times 10^{3}$ and $2.7 \times 10^{5} \mathrm{cfu} \cdot \mathrm{ml}^{-1}$ for Vuwani River and $6.2 \times 10^{4}$ and $7.9 \times 10^{4} \mathrm{cfu} \cdot \mathrm{ml}^{-1}$ for Ngwedi River. The maximum allowable limit for no risk in terms of heterotrophic bacterial count is $1.0 \times 10^{2}$ $\mathrm{cfu} \cdot \mathrm{ml}^{-1}$ (DWAF, 1996, WRC, 1998). Enterococci counts ranged from $2.0 \times 10^{3}$ and $5.5 \times 10^{3} \mathrm{cfu} \cdot \mathrm{ml}^{-1}$ for Masetoni point, between 5.0 $\times 10^{2}$ and $2.3 \times 10^{3}$ for Mhinga point, between $1.2 \times 10^{3}$ and $3.1 \times$ $10^{3}$ for Tshikonela point, between $1.0 \times 10^{3}$ and $1.0 \times 10^{3} \mathrm{cfu} \cdot \mathrm{ml}^{-1}$ for Didi point, between $4.0 \times 10^{3}$ and $2.1 \times 10^{4}$ for Grootpad point, between $1.9 \times 10^{3}$ and $2.5 \times 10^{4}$ for Mutoti point of the Levubu River; between $1.9 \times 10^{2}$ and $2.5 \times 10^{3} \mathrm{cfu} \cdot \mathrm{ml}^{-1}$ for Mutale River and between $4.0 \times 10^{1}$ and $3.2 \times 10^{2} \mathrm{cfu} \cdot \mathrm{ml}^{-1}$ for Tshinane River, between $1.0 \times 10^{1}$ and $5.1 \times 10^{2}$ for Vuwani River and between 6.6 x $10^{3}$ and $2.2 \times 10^{4} \mathrm{cfu} \cdot \mathrm{ml}^{-1}$ for Ngwedi River. The maximum recommended limit for no risk is $5 \mathrm{cfu} \cdot 100 \mathrm{ml}^{-1}$ (DWAF, 1996; WRC, 1998).
Coliphage counts obtained from the various water sources are presented in Table 3 . Briefly, coliphage counts ranged between 0 and $5 \mathrm{pfu} \cdot \mathrm{ml}^{-1}$ for Vuwani River, between 0 and $13 \mathrm{pfu} \cdot \mathrm{ml}^{-1}$ for Ngwedi River, between 0 and $7 \mathrm{pfu} \cdot \mathrm{ml}^{-1}$ for Tshinane River and Tshikonelo point of the Levubu River respectivey, between 0 and $3 \mathrm{pfu} \cdot \mathrm{ml}^{-1}$ for Mutale, Mudaswali and Mutshindudi Rivers respectively. Coliphages were not detected in Makonde and Mudaswali Fountains. The maximum recommended limit for no risk in terms of coliphage count is $1 \mathrm{pfu} \cdot 100 \mathrm{ml}^{-1}$.

The high number of indicators detected revealed that the microbiological quality of the water sources used was poor, unsafe and not acceptable for human consumption. The microbial quality of the water sources exceeded the maximum safety limit for drinking water as stipulated by the water quality guidelines. This is in agreement with findings by other researchers who conducted similar studies in rural areas (Palupi et al., 1995; Nevondo and Cloete, 1999).

The detection of somatic phages in the water sources with the exception of Mudaswali and Makonde Fountains could indicate possible viral contamination. However, there is controversy since some research has indicated that viruses have not been detected although phages were detected and in other cases viruses have been detected while phages were not. Phages can therefore only serve as indicators or as possible models to indicate potential presence of viruses (Grabow et al., 1984; Armon et al; 1997; Grabow et al; 2000; Grabow, 2001).

Potential pathogenic enteric bacteria such as Escherichia coli, Vibrio cholerae, Aeromonas hydrophila, Shigella, Plesiomonas and Campylobacter species were isolated from the various river water sources. The presence of these pathogens in river water sources is in agreement with previous reports (Nevondo and Cloete, 1999; Theron, 2001). These enteric bacteria are reportedly causative agents of various diseases and their complications (Grawbow, 1996). Such diseases include dysentery caused mainly by Shigella species, Guillian-Barre syndrome which is a complication of Campylobacter jejuni/coli infection, haemolytic uraemic 
syndrome which is a sequel of Eschericha coli, cholera and its associated manifestations such as hypovalaemic shock, acidosis and haemoconcentration which may be due to Vibrio cholerae. Typhoid fever is caused by Salmonella typhi; clinical manifestations of typhoid fever include septicaemia, cholecystitis and in some cases, typhoid psychosis. Consequently, the potential health risk posed by the consumption of water from river sources by rural residents and consumers in the Venda region must not be underestimated.

Possible sources of contamination of the river water sources include human and animal faeces or introduction of micro-organisms by birds and insects (Paul et al., 1995; Nevondo and Cloete, 1999; Lehloesa and Muyima, 2000). Most of the river sources are reportedly prone to higher bacterial levels due to heightened ecological activities, and may therefore not be suitable for human consumption (Lazorchak et al., 1998). These multiple sources of contamination are compounded by limited environmental awareness in rural areas (Lehloesa and Muyima, 2000).

It should, however, be noted that the presence of faecal coliforms in the water sources may not be definitive for a faecal origin of the bacteria (Paul et al., 1995). Investigators have reported the presence of faecal coliforms in tropical environments in the absence of any source of faecal contamination (Hardina and Fujioka, 1991, Hazen, 1998). For this reason, we employed an additional faecal indicator, enterococci. Enterococci may be better indicators of human faecal pollution in water (Levin et al., 1975; Rice et al., 1993) and they are reportedly better indicators of risk to swimmers of contracting gastrointestinal illness, due mainly by enteric viruses in sewage contaminated waters (Cabelli, 1983; Paul et al., 1995).

This study and other studies on domestic consumption of water in rural communities in the developing world (Palupi et al., 1995; Nevondo and Cloete, 1999; Acho-chi, 2001; Lehloesa and Muyima, 2001) showed the challenges for health and water resources in South Africa and other developing countries. The provision of potable water for rural communities is important in order to satisfy basic needs and is easily seen as crucial for assessing social development in developing countries (Forch and Biemann, 1998; Acho-chi, 2001). The South African government is thus, once again, alerted about the urgent need to address water supply problems in rural communities, where a substantial proportion of the populace reside.

According to the results it can be concluded that the microbial quality of the water sources was poor and unacceptable for human consumption due to faecal pollution. This indicates the potential risk of infection for consumers and calls for prompt intervention to mitigate the socio-economic and health impact of water-borne diseases in these rural communities.

\section{Acknowledgements}

We are grateful to the Water Research Commission (WRC), South Africa for providing the funds for the study, through a research grant awarded to the University of Venda for Science and Technology, South Africa. We are also appreciative of the role of Prof WOK Grabow for providing technical guidance especially on the virological studies. Ms APM Oelofse, Dr MNB Momba and other members of the Steering Committee of the WRC are thanked for their constructive criticisms and advice.

\section{References}

ACHO-CHI C (2001) Management of water supply system in the Kano district of Nigeria: Problems and possibilities. AQUA 50 (4) 199-207.
ALABI SA and ODUGBEMI TO (1990) Occurrence of Aeromonas species and Plesiomonas shigelloides in patients with and without diarrhoea in Lagos, Nigeria. J. Med. Microbiol 32 45-48.

ARMON R, ARAUJO R, KOTH Y, LUCENA F and JOFRE J (1997) Bacteriophages of enteric bacteria in drinking water. Comparison of their distribution in two countries. J. Appl. Microbiol. 83 627-633).

CABELLI VJ, DUFOUR AP, McCABE LJ and LEVIN MA (1983) A marine water quality criterion consistent with indicator concepts and risk analysis. J. Water Pollut. Control Fed. 551306-1314.

COKER AO and DOSUNMU-OGUMBI O (1984) Isolation of Campylobacter jejuni in Lagos, Nigeria. A new bacterial agent of diarrhoea. East Afr. Med. J. 61 52-55.

DEPARTMENT OF WATER AFFAIRS AND FORESTRY (DWAF) (1996) South African Water Quality Guideline for Domestic Use (2 $2^{\text {nd }}$ edn.), Pretoria.

FORCH G and BREMANN H (1998) Restoration of water supply schemes in the context of town development: The Bhaktapur project in Nepal. Appl. Geogr. Dev. 15 54-61.

GENTHE B and SEAGER J (1996) The Effect of Water Supply, Handling and Usage on Water Quality in Relation to Health Indices in Developing Communities. WRC Report No 562/1/96, Pretoria, South Africa.

GRABOW WOK, COUBROUGH P, NUPEN EM and BATEMAN BW (1984) Evaluations of coliphages as indicators of the virological quality of sewage-polluted water. Water SA 10 (1) 7-14.

GRABOW WOK (1996) Waterborne diseases: Update on water quality assessment and control. Water SA 22 193-202.

GRABOW WOK, TAYLOR MB, CLAY CG and DE VILLIERS JC (2000) Molecular detection of viruses in drinking water: Implications for safety and distribution. Proc. $2^{\text {nd }}$ Conf. of the Int. Life Science Inst. The safety of water disinfection: Balancing chemical and microbiological risks. Radisson Deauville Resort, Miami, Florida, USA. 1517 November.

GRABOW WOK (2001) Bacteriophages: Update on application as models for viruses in water. Water SA 27 (2) 251-268.

HARDINA CM and FUJIOKA RS (1991) Soil: The environmental source of Escherichia coli and enteroccocci in Hawaii's streams. Environ. Toxicol. Water Qual. 6 185-195.

HAZEN TC (1998) Faecal coliforms as indicators in tropical waters: A review. Toxic. Assess. 3 461-477.

JOSEPH T (1987) The isolation rates of pathogenic bacteria from stools of gastro-enteritis patients. Ind. Microbiol. 25 189-193.

LACORCHAK JM, KLEM DJ and PECK DV (eds.) (1998) Environmental Monitoring and Assessement Program - Surface Waters: Field Operations and Methods for Measuring the Ecological Condition of Wadable Streams. EPA/620/R-94/004F. US Environmental Protection Agency, Washington DC.

LEHLOESA L J and MUYIMA NYO (2000) Evaluation of the impact of household treatment procedures on the quality of groundwater supplies in the rural community of the Victoria district, Eastern Cape. Water SA 26 (2) 285-290.

LEVIN MA, FISCHER JR and CABELLI VJ (1975) Membrane filtration technique for enumeration of enterococci in marine waters. Appl. Environ. Microbiol. 30 66-71.

NEVONDO TS and CLOETE TE (1999) Bacterial and chemical quality of water supply in the Dertig village settlement. Water SA 25 (2) 215-220.

OBI CL, COKER AO, EPOKE J and NDIP R (1997) Enteric bacterial pathogens in stools of residents of urban and rural region in Nigeria: $\mathrm{A}$ comparison of patients with diarrhoea and controls without diarrhoea. J. Diarrhoeal Dis. Res. 15 (4) 241-247.

OGUNSANYA TI, ROTIMI VO and ADENUGA . (1994. A study of the etiological agents of childhood diarrhoea in Lagos, Nigeria. J. Med. Microbiol. 40 10-14.

PALUPI K, SUMENGEN S, INSWIASRI S, AUGUSTINA L, NUNIK SA, SUNARYA W and QURAISYN A (1995) River water quality study in the vicinity of Jakarta. Water Sci. Technol. 39 17-25.

PAUL JH, ROSE JB, JIANG S, KELLOG C and SHINN E (1995) Occurrence of faecal indicator bacteria in surface water and the subsurface equiter in Key Largo, Florida. Appl. Environ. Microbiol. 61 (6) $2235-2241$.

RICE EW, COVERT TC, WILD DK, BERMAN D, JOHNSON SA and JOHNSON CH (1993) Comparative resistance of Escherichia coli and enterococci to chlorination. J. Environ. Sci. Health A 28 (1) 89-97. 
SCHALEKAMP M (1990) The UNO-drinking water decade 1990-1991: Problems and successes. Lecture held on the occasion of the $100^{\text {th }}$ Anniversary of the Austrian Gas and Water Industry. Water Supply, Zürick, Industrial Corporations of the City of Zürick, Bombay.

SIMANGO C, DINDIWE J and RUKURE G (1992) Bacterial contamination of food and household stored drinking water in a farm working community in Zimbabwe. Centr. Afr. J. Med. 38 (4) 143-148.

STANDARD METHODS (1998) Standard Methods for the Examination of Water and Wastewater (20 ${ }^{\text {th }}$ edn.) Clesceri LS, Greenberg AE and Eaton AD (eds.). American Public. Health Association, Washington DC.

THERON J (2001) The challenge of identifying waterborne pathogens leads to new technology. SA Waterbulletin 27(3) 10-13.
VON GRAVENITZ A (1985) Aeromonas and Plesiomonas. In: Lenneth EHM, Balows A, Hansler WJ and Shadomy HJ (eds.) Manual of Clinical Microbiology. Washington Society of Microbiology. 278282.

WATER RESEARCH COMMISSION (WRC) 1993) Guidelines on the Cost Effectiveness of Rural Water Supply and Sanitation Projects. WRC Report No. 231/1/93, Pretoria, South Africa.

WATER RESEARCHCOMMISSION (WRC) (1998) Quality of Domestic Water Supplies. Vol. 1- Assessment Guide. WRC Report No TT101/ 98. Pretoria, South Africa.

WHO (1993) Guidelines for Drinking Water Quality. Vol. 1. Recommendations ( $2^{\text {nd }}$ edn.). World Health Organisation, Geneva, Switzerland. 